\title{
GENDER DIFFERENCES IN PRACTICE, KNOWLEDGE AND ATTITUDES REGARDING FOOD HABITS AND MEAL PATTERNS AMONG COMMUNITY DWELLING OLDER ADULTS
}

\author{
J. Johannesson ${ }^{1}$, E. Rothenberg', ${ }^{1,2}$ S. Dahlin Ivanoff,, F. Slinde
}

\begin{abstract}
Objective: To study gender differences in older adults according to practice, knowledge and attitudes regarding food habits and meal patterns. Design: Cross-sectional study. Setting: Two urban districts of Gothenburg, Sweden. Participants: A total of 297 individuals were included, 102 men and 195 women. They were 80 years or older and living in ordinary housing without being dependent upon the municipal home help services or help from another person in Activities of Daily Life, and cognitively intact, defined as having a score of 25 or higher in the Mini Mental State Examination. Measurements: Telephone interviews regarding food habits and meal patterns were conducted. Results: Almost all participants $(99 \%)$ ate their main meal at home and men preferred company at meals more often $(\mathrm{p}<0.001)$. Women had the sole responsibility to shop for food more often $(\mathrm{p}<0.000)$, and generally regarded cooking as a routine or something they just had to do. Among men, few (13\%) took a great interest in cooking and $36 \%$ of the men stated that cooking was something they were not capable of performing $(\mathrm{p}<0.000)$. Men had company at meals every day more often $(71 \%$ vs $40 \%)$. Respondents stated that loneliness took away the enjoyment of cooking and changed their habits when becoming a widow or widower. Conclusion: Women take greater responsibility for the household than men, regardless of marital status. A large proportion of the men thought cooking was something they were not able to do. The findings in this study may indicate a possible gender difference in the need for societal support.
\end{abstract}

Key words: Aged 80 and over, nutritional status, food habits, household responsibilities, lived experience.

\section{Introduction}

As aging is an individually varying process influenced by various factors, such as lifestyle, disease and genetic disposition, older adults therefore form a heterogeneous group (1). As long as older adults stay healthy they seem to maintain good food habits and nutritionally adequate diets. This has been shown in several population based studies such as the H70 which was performed in Sweden $(2,3)$, and the SENECA-study which was performed in seven different countries (4).

Malnutrition could be defined as a nutritional state of lack or excess of energy, protein and other nutrients that cause measurable adverse effects on body structure, function and clinical course (5). Studies on independent living older adults show that there is a significant association between individuals suffering

1. Sahlgrenska Academy, Department of Internal Medicine and Clinical Nutrition, University of Gothenburg, Sweden; 2. Kristianstad University, School of Education and Environment, Sweden; 3. Sahlgrenska Academy, Department of Neuroscience and Physiology, University of Gothenburg, Sweden.

Corresponding Author: J. Johannesson, Sahlgrenska Academy, Department of Internal Medicine and Clinical Nutrition, University of Gothenburg, Sweden, julie. johannesson@gu.se from poor nutritional status and an increasing level of frailty (6) and disease (7). Naseer et al's study on home-living and special housing residents showed that the risk of malnutrition was associated with a higher risk of mortality (8). Among hospitalized, older, chronically ill adults almost half are malnourished (9). The reasons are lower reserves of physiological and psychological systems, multiple chronic diseases and many drugs in combination which may lead to increased morbidity and mortality (10). Unintentional weight loss is also an indicator of frailty, and could be defined as "psychological state of increased vulnerability to stressors that result from decreased physiologic reserves, and even dysregulation, of multiple physiologic systems" (11), with increasing incidence by age and with negative health consequences. Frailty has been reported to be up to twofold higher in women than men (12). A consensus group of gerontology researchers recommends that physical frailty should be measured according to the phenotype model developed by Fried and co-workers, which takes into account the presence of three or more of the following criteria: unintentional weight loss, selfreported exhaustion, low energy expenditure, slow gait speed and weak grip strength (13). 
Factors such as appetite (14), ability to chew and swallow (15), and smell and taste (16) may be affected by frailty, therefore it is important to reach a better understanding of how these factors influence eating and the ability to satisfy nutritional needs in old age.

In $2014,5 \%$ of the Swedish population were 80 years of age or older, $62 \%$ of them were women and $38 \%$ men (17). Among these, $23.8 \%$ (30\% men, $70 \%$ women), were approved home help service and $14 \%$ lived permanently in special housing (27\% men and $73 \%$ women). The figures for Gothenburg were similar (18). About 2/3 of this population live in ordinary housing and are not dependent on the municipal home help service or care.

Vitolins et al (19) studied gender variation in dietary intake among rural older adults ( $\geq 70 \mathrm{yrs})$ in the United States. Men had significantly higher nutrient intake than women, and age was not significantly associated with the intake levels of any of the measured nutrients. To our knowledge, there are few studies concerning gender differences in nutritional risk (20-22).

Sidenvall et al (23) found that widows and single women did not enjoy cooking for themselves and thought it was difficult to plan their food only for themselves, therefore they often left out meals. Cohabiting women planned their cooking according to their husbands' taste. Meals with company were enjoyed most, and taken for granted by cohabiting women. Single women lost their appetite due to loneliness and the lack of everyday company (23). Wham and Bowden (24) found that eating alone was the most common nutrition risk factor among single-living men in New Zealand. Individual circumstances influenced their eating practices; limited finances and lack of personal transport also limit healthy eating. There was also a lack of nutrition knowledge and cooking skills among the participating men. However, Morais et al (25) and Saka et al (26) found that gender did not have a significant impact on nutritional risk. Quandt and Chao (21) found that women were at increased nutritional risk compared to men using the Nutritional Risk Index (NRI), women also had a higher average age and they were more likely to live alone. Men were more often married whilst women were widows.

Due to the increasing life expectancy and due to the lack of studies, there is a great need for knowledge and understanding of how food habits and meal patterns affect older people's capability to maintain independence and health. Several factors are involved. In the present paper we have chosen to look specifically at the gender aspect since in these age groups men and women in general have had different roles in the household with women by tradition taking a greater responsibility for food supply and cooking.

The aim of this study was therefore to study gender differences among community dwelling older adults according to practice, knowledge and attitudes regarding food habits and meal patterns.

\section{Methods}

\section{Participants and setting}

Participants were recruited from the one-year followup of "Elderly in the risk zone" (EPiR) (27) conducted 2008 to 2011 in two urban districts in Gothenburg, the second largest city in Sweden with approximately 600 000 inhabitants. In the two districts people 80 years and older account for $8 \%$ and $7 \%$ respectively of the population, compared to 5\% of Gothenburg and Sweden as a whole (28). They are situated outside the city centre but within the city limits, and contain a mix of selfowned houses and apartment buildings. The general educational and income levels are slightly higher, and the prevalence of disease somewhat lower, than in the general population of Gothenburg (29). The EPiR study included 459 community-dwelling individuals aged 80 years of age or over. Those who were independent of help from the community in all activities according to Activities of Daily Living (ADL) and with a Mini Mental State Examination (MMSE) (30) of $>25$ at baseline were included. After one year 366 individuals remained in the EPiR study and were eligible for the current study. The main reason for drop-out between baseline and oneyear follow-up in the EPiR-study was "not interested". Remaining individuals were invited to the current study and 297 accepted participation (Figure 1 and table 1).

\section{Figure 1}

Flow of the participants throughout the study. Reasons for declining participation.

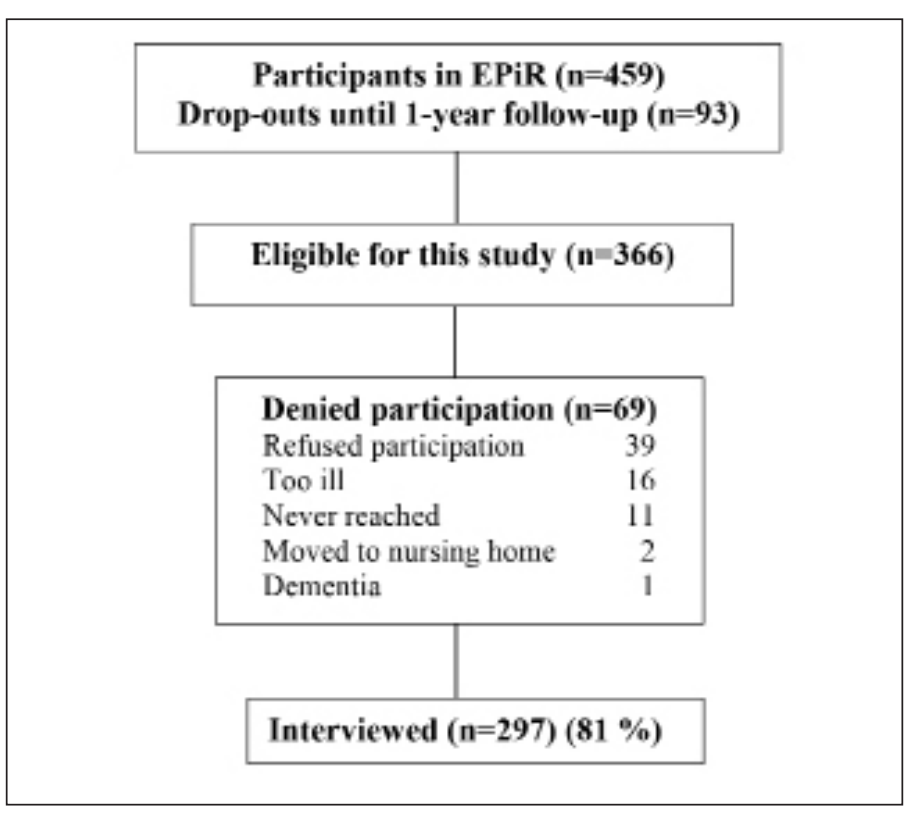


Table 1

Characteristics of the participants in the study, $\mathrm{n}(\%)$

\begin{tabular}{|c|c|c|c|c|}
\hline & Total sample $\mathbf{n}=\mathbf{2 9 7}$ & Men $\mathbf{n}=103$ & Women $\mathrm{n}=194$ & p-value ${ }^{1}$ \\
\hline Marital status, $n(\%)$ & & & & $<0.000$ \\
\hline Married/Cohabiting & $134(46)$ & $79(77)$ & $55(29)$ & \\
\hline Widow/Widower & $130(44)$ & $18(18)$ & $112(59)$ & \\
\hline Single/Divorced & $29(10)$ & $5(5)$ & $24(12)$ & \\
\hline Education, $n(\%)$ & & & & $<0.000$ \\
\hline Lower education & $236(79)$ & $70(68)$ & $166(86)$ & \\
\hline Higher education or University degree & $61(21)$ & $33(32)$ & $28(14)$ & \\
\hline Type of housing, $n(\%)$ & & & & 0.034 \\
\hline Rented flat & $128(44)$ & $43(43)$ & $85(45)$ & \\
\hline Condominium & $93(32)$ & $25(25)$ & $68(36)$ & \\
\hline Villa/town house & $69(24)$ & $32(32)$ & $37(19)$ & \\
\hline Dental status, $n(\%)$ & & & & 0.944 \\
\hline Own teeth & $153(52)$ & $53(52)$ & $100(51)$ & \\
\hline Partially own teeth & $111(37)$ & $40(39)$ & $71(37)$ & \\
\hline Dental implants & $17(6)$ & $5(5)$ & $12(6)$ & \\
\hline Dentures & $16(5)$ & $5(4)$ & $11(6)$ & \\
\hline$B M I$ & & & & 0.363 \\
\hline$<24 \mathrm{~kg} / \mathrm{m}^{2}$ & $159(56)$ & $54(53)$ & $105(58)$ & \\
\hline $24-29 \mathrm{~kg} / \mathrm{m}^{2}$ & $99(35)$ & $41(40)$ & $58(32)$ & \\
\hline$>29 \mathrm{~kg} / \mathrm{m}^{2}$ & $24(9)$ & $7(7)$ & $17(9)$ & \\
\hline Weight, $n(\%)$ & & & & 0.426 \\
\hline Satisfied & $207(70)$ & $75(73)$ & $132(68)$ & \\
\hline Wish to gain & $11(4)$ & $5(5)$ & $6(3)$ & \\
\hline Wish to lose & $78(26)$ & $23(22)$ & $55(29)$ & \\
\hline Weighed themselves regularly, $n(\%)$ & & & & 0.082 \\
\hline Yes & $167(56)$ & $65(63)$ & $102(53)$ & \\
\hline No & $130(44)$ & $38(37)$ & $92(47)$ & \\
\hline Weight change since working age, $n(\%)$ & & & & 0.155 \\
\hline Gained & $79(27)$ & $21(20)$ & $58(30)$ & \\
\hline Lost & $94(32)$ & $33(32)$ & $61(32)$ & \\
\hline Stable & $123(41)$ & $49(48)$ & $74(38)$ & \\
\hline
\end{tabular}

1. Chi-square test

Assessment of practice, knowledge and attitudes regarding food habits and meal patterns

To assess practice, knowledge and attitudes regarding food habits and meal patterns a telephone interview was performed using a questionnaire. The questionnaire was partly based on questions from two previous Swedish population studies $(2,31)$, with the addition of new questions for the purpose of the present study. In this study, food habits could be understood as the way in which people select, cook, serve and eat food that is available to them. Meal pattern was identified using the method from Bertéus Forslund et al (32), and was defined as all intake occasions of any food or drink consumed at any time point.

Attitude is defined as the way that one thinks and feels about somebody or something and the way that one behaves towards somebody or something that shows ones thoughts and feelings (33). Practice is to perform or do something regularly as an ordinary part of one's life 
(33).

Background variables such as age, gender, marital status, type of housing and education were collected from baseline data in EPiR (27).

The questionnaire was tested, using a telephone interview, on a small group $(\mathrm{n}=5)$ from the EPiR-cohort, and revised according to reflections from the interviewer and comments from the respondents. The final questionnaire consisted of 52 questions. Those concerning food choices and food habits were open questions; the remaining had given alternatives.

The questionnaire started with questions regarding shopping and cooking responsibilities, followed by questions concerning eating alone or with others, location of eating and if there were problems associated with eating and dental status. Further on, opinions concerning foods and health, followed by meal patterns, were asked for. Those who had home delivered meals ("meals on wheels") were requested to answer how often they received meals and if they had a choice of different meals. The questionnaire ended with questions regarding earlier food habits, appetite, self-reported body weight and height and time point for these last measurements.

Body Mass Index (BMI) calculated as $\mathrm{kg} / \mathrm{m}^{2}$ and based on self-reported weight and height, was used as a crude measure of nutritional status. The cut-off for underweight was set at BMI $<24 \mathrm{~kg} / \mathrm{m}^{2}$, normal weight BMI $24-29 \mathrm{~kg} / \mathrm{m}^{2}$ and overweight $>29 \mathrm{~kg} / \mathrm{m}^{2}$ according to Beck and Ovesen (34).

The interviews were conducted by an experienced dietician (JJ) and lasted for 16 minutes (6-74) in mean. Six persons had hearing problems and were asked to fill in the form at home and return it by post.

\section{Statistical analyses}

The descriptive results are presented as mean and standard deviation. To analyse differences between groups the Chi2 test was used. Student's t-test was used for continuous variables. Two-sided significance tests were used throughout. Statistical significance was accepted at the $5 \%$ level $(\mathrm{p}<0.05)$. Statistical analyses were performed using PASW Statistics, version 21.0 (IBM SPSS Inc, Chicago, IL).

A power calculation was performed at baseline for the EPiR-study and it was estimated that about 450 individuals would need to be included to allow for dropouts. This study is conducted at the one-year follow-up (35).

\section{Ethical considerations}

The study was approved by the Regional Ethical Review board in Gothenburg ref no: 650-07.

The information to the participants was given both in a written letter and in person and it was clearly stated that participation was completely voluntary and they could decline at any time without giving a reason.

\section{Results}

To the present study, the remaining 366 individuals from the one year follow-up from the EPiR-cohort were invited. Eligible individuals received a letter with an invitation to a telephone interview regarding practice, knowledge and attitudes regarding food habits and meal patterns. The questionnaire was also included in the letter. The letter was followed by a telephone interview after a week when eligible individuals could accept or refuse participation. The flowchart of participation is shown in Figure 1.

Sixty-nine individuals $(19 \%)$ did not agree to participate in the current study. There was no significant difference concerning gender, marital status, and type of living or education among the individuals who denied participation compared to the participants. Regarding age there was a significant difference; the ones who did not participate were significantly older. The main reason for declining participation was "not interested" (9\%). Since participating in the EPiR, 18 individuals were deceased (4 \%) (Figure 1).

Among those interviewed, $66 \%$ were women; mean age 87 yrs $(S D \pm 3)$ for both genders (range 83-100). Marital status, level of education, type of housing and dental status is shown in table 1 . Women had a higher education more seldom and were more often widows, compared to men (table 1). At the time of retirement, nine per cent $(n=18)$ of the women were housewives, none of the men $(\mathrm{p}=0.000)$.

A majority, $70 \%(\mathrm{n}=207)$, reported that they were satisfied with their present body weight and $56 \%(\mathrm{n}=167)$ used to weigh themselves regularly, yet $26 \%(\mathrm{n}=78)$ expressed a wish to lose weight and $4 \%(\mathrm{n}=11)$ had a wish to gain weight (table 1). Self-reported mean BMI was $24 \mathrm{~kg} / \mathrm{m}^{2}$ (range $\left.15.4-37.3 \mathrm{~kg} / \mathrm{m} 2\right)\left(\mathrm{SD} \pm 3.2 \mathrm{~kg} / \mathrm{m}^{2}\right)$ for both genders (table 1).

Concerning appetite, $91 \%(\mathrm{n}=94)$ of men and $86 \%$ $(n=166)$ of women reported good or very good appetite. Among those who considered themselves having a poor appetite, $69 \%(n=24)$ reported a BMI lower than 24 $\mathrm{kg} / \mathrm{m} 2$ and $57 \%(\mathrm{n}=21)$ (both genders) were widows / widowers, ns.

Both genders, men $76 \%(\mathrm{n}=78)$, and women $68 \%$ $(n=130)$, considered that their appetite had remained stable since working age; difference (ns) between genders.

\section{Practice regarding food habits and meal patterns}

Independent of gender almost all participants had their main meal at home; only a few $(n=4)$ went to a restaurant or meeting place for seniors. A small number $(2 \%, \mathrm{n}=7)$ received ready-to-serve meals (meals on wheels). 
Table 2

Participant's practice, knowledge and attitudes regarding food habits and meal patterns, n (\%)

\begin{tabular}{|c|c|c|c|c|}
\hline & Total sample $\mathbf{n}=297$ & Men $n=103$ & Women $n=194$ & p-value ${ }^{1}$ \\
\hline \multicolumn{2}{|l|}{ I usually have my main meal, $n(\%)$} & & & 0.089 \\
\hline At home & $292(99)$ & $100(97)$ & $192(99)$ & \\
\hline Restaurant/Senior meeting place & $4(1)$ & $3(3)$ & $1(1)$ & \\
\hline Relatives' house & $0(0)$ & $0(0)$ & $0(0)$ & \\
\hline Other & $0(0)$ & $0(0)$ & $0(0)$ & \\
\hline \multicolumn{2}{|l|}{ Eating with company, frequency, $n(\%)$} & & & $<0.000$ \\
\hline Almost every day & $119(40)$ & $73(71)$ & $46(24)$ & \\
\hline Once a week & $70(24)$ & $12(12)$ & $58(30)$ & \\
\hline More seldom & $100(34)$ & $16(15)$ & $84(43)$ & \\
\hline Never & $7(2)$ & $2(2)$ & $5(3)$ & \\
\hline \multicolumn{2}{|c|}{ Appreciates food as before the age of $65, n(\%)$} & & & $<0.001$ \\
\hline Yes & $214(72)$ & $87(85)$ & $127(66)$ & \\
\hline No & $82(28)$ & $16(15)$ & $66(34)$ & \\
\hline \multicolumn{2}{|l|}{$\begin{array}{l}\text { Attitudes towards company at meals, } n \\
(\%)\end{array}$} & & & $<0.001$ \\
\hline Yes & $201(70)$ & $85(84)$ & $116(63)$ & \\
\hline No & $85(30)$ & $16(16)$ & $69(37)$ & \\
\hline \multicolumn{2}{|c|}{ Avoids foods and beverages related to health, $n(\%)$} & & & 0.035 \\
\hline Yes & $95(32)$ & $25(24)$ & $70(36)$ & \\
\hline No & $201(68)$ & $78(76)$ & $123(64)$ & \\
\hline \multicolumn{2}{|l|}{ Changed habits in recent years ${ }^{2}, n(\%)$} & & & 0.007 \\
\hline Yes & $114(38)$ & $29(28)$ & $85(44)$ & \\
\hline No & $182(62)$ & $74(72)$ & $108(56)$ & \\
\hline
\end{tabular}

1 Chi-Square test; 2 Habits regarding cooking, meal patterns and choice of foods.

Compared to women, men more often had company at meals every day (table 2$)$. Nevertheless, $77 \%(\mathrm{n}=79)$ of men had a wife or cohabitant compared with $29 \%(\mathrm{n}=55)$ of the women. If there was a choice, $84 \%(n=85)$ of the men and just $2 / 3$ of the women $(63 \%, n=116)$, preferred to have company at meals.

Regarding eating related problems, no significant differences between the genders were found (table 2).

Women tend to avoid different kinds of foods or beverages, related to their health more often compared to men. Sweet foods (15\%), indigestible foods (14\%), fatty foods $(13 \%)$ and different kinds of fruits and vegetables $(13 \%)$ were the most commonly reported. The main reasons for excluding these foods were different kinds of digestive symptoms (36\%), diabetes (13\%) and bile problems (9\%).

A larger proportion of women reported that their habits regarding cooking, meal patterns and choice of foods had changed during recent years $(p=0.007)$. The main reasons were becoming a widow $(41 \%)$ or their own retirement (19\%) (table 2).

\section{Knowledge and attitudes regarding food habits and meal patterns}

Women more often than men went shopping for food on their own and men reported more frequently that their spouse/cohabitant did the food shopping. Both women and men reported that women were the ones 
Table 3

Participants practice, knowledge and attitudes regarding food habits, n (\%)

\begin{tabular}{|c|c|c|c|c|}
\hline & Total sample $n=297$ & Men $n=103$ & Women $n=194$ & p-value ${ }^{1}$ \\
\hline Who does the shopping, $n(\%)$ & & & & $<0.000$ \\
\hline Myself & $173(58)$ & $38(37)$ & $135(70)$ & \\
\hline Myself with company & $79(27)$ & $41(40)$ & $38(20)$ & \\
\hline Spouse & $27(9)$ & $20(19)$ & $7(3)$ & \\
\hline Others & $18(6)$ & $4(4)$ & $14(7)$ & \\
\hline Responsible for what to buy, $n(\%)$ & & & & $<0.000$ \\
\hline Myself & $199(67)$ & $36(35)$ & $163(84)$ & \\
\hline Myself with company & $61(20)$ & $36(35)$ & $25(13)$ & \\
\hline Spouse & $36(12)$ & $31(30)$ & $5(2)$ & \\
\hline Others & $1(1)$ & $0(0)$ & $1(1)$ & \\
\hline \multicolumn{5}{|l|}{ Mainly does the cooking, $n(\%)$} \\
\hline Myself & $212(71)$ & $34(33)$ & $178(92)$ & $<0.000$ \\
\hline Myself with company & $20(7)$ & $15(15)$ & $5(2)$ & \\
\hline Spouse & $56(19)$ & $50(48)$ & $6(3)$ & \\
\hline Relatives / Friends/Neighbours & $3(1)$ & $2(2)$ & $1(1)$ & \\
\hline Delivered meals & $6(2)$ & $2(2)$ & $4(2)$ & \\
\hline Attitudes about cooking, $n(\%)$ & & & & $<0.000$ \\
\hline Not able to do & $45(15)$ & $37(36)$ & $8(4)$ & \\
\hline Just have to do & $55(19)$ & $18(18)$ & $37(19)$ & \\
\hline An obvious routine & $146(49)$ & $34(33)$ & $112(58)$ & \\
\hline A great interest & $50(17)$ & $13(13)$ & 37 (19) & \\
\hline
\end{tabular}

1 Chi-Square test

who were responsible for shopping at the store rather than men (table 3). A large percentage of both men and women still appreciated food as much as they did before they were at the age of 65 (table 2). Among the married/ cohabiting respondents there was a significant difference $(p<0.000)$ between genders regarding responsibility for planning food shopping and cooking. The women more often had sole responsibility, and thought of cooking as a routine or something they just had to do, while some, $19 \%$, expressed great interest in cooking. Among men, few took a great interest in cooking and $36 \%$ stated that this was something they were not capable of performing (table 3).

\section{Discussion}

In this study we have identified several gender differences according to practice, knowledge and attitudes regarding food habits and meal patterns among community dwelling older adults indicating a possible gender difference in the need for societal support according to these matters.

\section{Materials and methods discussion}

Subject characteristics indicate that the present population is in better condition than Swedish 80-year olds in general (36); education and income levels were somewhat better; $56 \%$ own their homes; prevalence of disease is slightly lower and at baseline they were independent in ADL (29). Lindblad et al (37) studied a sub-sample of individuals from EPiR; results showed that body energy and protein stores and muscle strength were well-preserved in this group indicating good functional status.

Almost $50 \%$ still lived with their spouse or a cohabitant, and as shown by Larsson et al (38), marital status is significantly connected with the use of eldercare and home help; unmarried and single people, both men and women, are more likely to receive home help services and to move in to institutional care than those living with a spouse. Among persons 65 years or older in Gothenburg, 10 per cent receive home help (39). This is important when interpreting differences among participants with regard to activities in the household such as shopping for food or cooking. 
Since participants already participated in the EPiRstudy, many of them were motivated to answer an additional survey, which certainly contributed to the high response rate of $81 \%$. As the questionnaire was sent in advance, respondents were prepared and this made it easier for them to answer the questions during the telephone interview.

The questionnaire worked well, participants did not need explanation of the questions in detail. Even though it was extensive, respondents did not seem to get tired and they managed to answer adequately.

However, individuals with cognitive impairment had already been excluded from the EPiR interviews.

A weakness of this study is that we did not measure weight and height; these figures are self-reported. A measurement taken by the interviewer may have given a more reliable result, but was not possible due to telephone interview. Also, the study took place in two prosperous districts and as community demographics have an impact on public health interventions, this might have affected the results and limits generalisation (40).

The strength is that, to our knowledge, there are few studies concerning gender differences among elderly individuals living in their own homes regarding practice, knowledge and attitudes regarding food habits and meal patterns in accordance with their capability to maintain independence and health.

Power et al (41) studied the frequency of consumption of the major food groups among a group of elderly and detected gender differences especially among males aged 64-75 yrs. Maharana et al (42) studied gender differences concerning health and food expenditures and findings indicated a wide gender disparity, being higher among men than women, though narrowing the gap with time.

\section{Results discussion}

Almost half of the female respondents reported that they had changed their habits regarding cooking, meal patterns and choice of foods during recent years. However, both genders thought their appetite had remained stable since working age. Sidenvall et al $(23,43)$ found that elderly individuals were affected by changes in their family; a loss of a spouse could mean losing the whole meaning of cooking, resulting in meal skipping and decreased nutrition intake. The results in the present study are in agreement with the findings by Sidenvall el al; loneliness was expressed as a reason for not enjoying cooking or eating alone (23). Tinker (44) stated that, the older a person becomes, isolation is increasingly recognized as a dilemma, and according to Dykstra et al (45), the increase in loneliness can be different depending on earlier family structures, i.e. single-living individuals can be less lonely and the ones whose spouse has died show the greatest increase in loneliness. Locher et al (20) noted that social isolation, low income level and limited independency in later life contributed to nutritional risks.
Gender was a risk factor for older person's nutritional intake. McDonald and co-workers interviewed widowers to identify risk for nutrition problems and considered that socioeconomic factors, informal and formal support were important for being able to maintain nutritional selfmanagement (46).

Sidenvall et al (23), also reported that elderly women did not want to go to a local restaurant as they found it depressing to eat with sick and disabled persons, and they did not like to talk to persons in the restaurant who they did not know.

The municipality provides a few dining places for seniors where it is possible to have a nutritious meal, and company. One dining place also has a meal hostess who assists the guests, although they are not so frequently visited by the respondents in this study; the reasons why are unknown to us but would be interesting to study further.

In the 1950's, $12 \%$ of married women and $90 \%$ of men were gainfully employed in Sweden (47). Since the country went through a social transition due to industrialization during the 20th century, women's position in society gradually changed with a growing proportion of women working outside the home, particularly after the Second World War (48). In the first half of the 20th century, men commonly left home for work while women took care of the children and the household, and with it, the cooking for the family. Fjellström found in her thesis that among the older generation women have had the duty to prepare, serve and cook food, even among those with paid employment (49). Furthermore, it has been shown that cooking is closely linked with feminine identity (50).

We only asked a few questions about cooking and we did not know what cooking knowledge the respondents had from earlier in life. Many men expressed that they were not interested or were unable to cook. It might also be a generational issue that women go more often to the food stores and are responsible for shopping; as she is the one who does the cooking, she therefore knows what needs to be bought. If the woman has always been the one who was in charge in the kitchen, she still is (43).

Food avoidance due to health problems was expressed during the interviews; a few persons said that they avoided certain kinds of foods they thought were unhealthy. The cause however, differed. Avoidance of food among community-dwelling older adults is not well described in the literature. Savoca et al (51) has studied avoidance and modification of foods among the elderly related to their dental and oral status, finding it related to significant differences in dietary quality. Quandt et al (52) found that whole fruit and raw vegetables were the most commonly avoided foods, also due to oral health. Quandt et al (52) considers that dietary variation is associated with health maintenance and disease prevention among older adults. However, the risk of a lower intake of energy and nutrients due to avoidance for other reasons 
is not well described in the literature.

As shown in table 1, the dental status among the participants in this study seems good; only $5 \%$ had dentures. A contributing reason could be, as stated, that the present population is in better condition than Swedish 80 year-olds in general, and dental status is related to socioeconomic status (53). Social network and lifestyle factors are significant predictors for dental status as shown by Österberg et al (53), concerning 70-year olds in Gothenburg. This is also confirmed by Hugoson and Koch (54) for another area in Sweden. Petersen and Yamamoto (55) showed that loss of teeth (edentulism) is highly associated with socio-economic status and is prevalent among the elderly all over the world.

There are few previous studies looking at gender differences according to practice, knowledge and attitudes regarding food habits and meal patterns among elderly. Most of the earlier studies are focused on nutrient intakes, malnutrition, pharmaceutics or other diseases and have often been carried out in nursing homes or in younger populations $(19,21,22,41,42,56-59)$.

Further studies of other socio-economic groups of older adults are needed. Whether the gender differences identified in the current study affect the development of frailty or malnutrition also remains to be studied in the future. Due to the increasing life expectancy and due to the lack of studies of older adults, there is a great need for knowledge and understanding of how food habits and meal patterns affect their capability to maintain independence and health and how gender influences these relationships. However, the findings in this study may indicate a possible gender difference in the need for societal support.

\section{Conclusions}

Women in the present study take a greater responsibility for the planning and cooking of meals than men, regardless of marital status. A large proportion of the men thought cooking was something they were not able to do. Both genders had a good or very good appetite and considered that their appetite had remained stable since working age. More than half of those who reported poor appetite were widows/widowers. Further studies of how food habits and meal patterns affect older people's capability to maintain independence and how gender influences these relationships are needed.

Acknowledgements: This study was accomplished while Julie Johannesson was affiliated with the Swedish National Graduate School for Competitive Science on Ageing and Health (SWEAH), which is funded by the Swedish Research Council. The authors would like to thank the Vårdal Institute for financial support.

\section{Conflict of interest: JJ, ER, SDI and FS have no conflicts of interest to declare.}

Ethical Standards: The study complies with the current laws of Sweden. The Regional Ethical Review board in Gothenburg ref no: 650-07.

\section{References}

1. WHO. Good health adds life to years Global brief for World Health Day 2012 [Internet]. 2012. Available from: http://www.who.int/world_health_ day / 2012

2. Rinder L, Roupe S, Steen B, Svanborg A. 70-year-old people in Gothenburg A population study in an industrialized Swedish city.1. General Presentation of study. Acta Med Scand. 1975;198(5):397-407.

3. Rothenberg E, Bosaeus I, Steen B. Intake of energy, nutrients and food items in an urban elderly population. Aging-Clinical Exp Res. 1993;5(2):105-16.

4. Haveman-Nies A, De Groot LPGM, Burema J, Amorim Cruz J, Osler M, Van Staveren W. Dietary quality and lifestyle factors in relation to 10-year mortality in older Europeans: The SENECA Study. Am J Epidemiol. 2002;156(10):962-8.

5. Stratton RJ, Green CJ, Elia M. Disease-related malnutrition. CABI; 2003.

6. Boulos C, Salameh P, Barberger-Gateau P. Malnutrition and frailty in community dwelling older adults living in a rural setting. Clin Nutr. 2015 Jan 21;

7. Bapen. Combating Malnutrition: recommendations for action [Internet]. 2009. Available from: http://www.bapen.org.uk/pdfs/reports/advisory_group_ report.pdf

8. Naseer M, Forssell H, Fagerström C. Malnutrition, functional ability and mortality among older people aged $\geq 60$ years: a 7 -year longitudinal study. Eur J Clin Nutr. Macmillan Publishers Limited; 2015 Nov 25;

9. Sullivan DH, Sun S, Walls RC. Protein - Energy Undernutrition Among Elderly Hospitalized Patients A Prospective Study. JAMA, J Am Med Assoc 1999;281(21):2013-9.

10. Akner G, Cederholm T. Treatment of protein-energy malnutrition in chronic nonmalignant disorders. Am J Clin Nutr. 2001;74(1):6-24.

11. Fried LP, Ferrucci L, Darer J, Williamson JD, Anderson G. Untangling the concepts of disability, frailty, and comorbidity: implications for improved targeting and care. J Gerontol A Biol Sci Med Sci. 2004;59(3):255-63.

12. Fried LP, Tangen CM, Walston J, Newman AB. Frailty in older adults: Evidence for a phenotype. J Gerontol A Biol Sci Med Sci. 2001;56(3):M146-56.

13. Morley JE, Vellas B, van Kan GA, Anker SD, Bauer JM, Bernabei R, et al. Frailty consensus: a call to action. J Am Med Dir Assoc. 2013 Jun;14(6):392-7.

14. Hickson M. Malnutrition and ageing. Postgrad Med J. 2006;82(963):2-8.

15. Shtereva N. Aging and oral health related to quality of life in geriatric patients. Rejuvenation Res. 2006;9(2):355-7.

16. Rawson NE. Olfactory loss in aging. Sci Aging Knowledge Environ. 2006 Feb 8;2006(5):pe6.

17. Statistiska Centralbyrån. Sveriges befolkning efter kön och ålder 31 december 2014 - Statistiska centralbyrån [Internet]. 2015 [cited 2015 Apr 17]. Available from: http://www.scb.se/sv_/Hitta-statistik/ Statistik-efter-amne / Befolkning / Befolkningens-sammansattning/ Befolkningsstatistik/25788/25795/Helarsstatistik---Riket/262459/

18. Socialstyrelsen. Befolkningsstatistik för äldreomsorgen 2012. [Internet]. 2012 [cited 2015 Jul 3]. Available from: http//:www.socialstyrelsen.se/statistik/ statistikdatabaser/aldreomsorg

19. Vitolins MZ, Quandt SA, Case LD, Bell RA, Arcury TA, McDonald J. Ethnic and Gender Variation in the Dietary Intake of Rural Elders. J Nutr Elder. 2000;19(December 2013):15-29.

20. Locher JL, Ritchie CS, Roth DL, Sawyer Baker P, Bodner E V, Allman RM. Social isolation, support, and capital and nutritional risk in an older sample: ethnic and gender differences. Soc Sci Med. 2005 Feb;60(4):747-61.

21. Quandt SA, Chao D. Gender Differences in Nutritional Risk Among Older Rural Adults. J Appl Gerontol. 2000;19(2):138-50.

22. Hendy HM, Nagle TR. A critical examination of gender differences in nutritional risk for rural adults with disability. Rehabil Psychol. 2002;47(2):219-29.

23. Sidenvall B, Nydahl M, Fjellström C. The Meal as a Gift--The Meaning of Cooking Among Retired Women. J Appl Gerontol. 2000;19(4):405-23.

24. Wham CA, Bowden JA. Eating for health: perspectives of older men who live alone. Nutr Diet. 2011;68(3):221-6.

25. de Morais C, Oliveira B, Afonso C, Lumbers M, Raats M, de Almeida MD V. Nutritional risk of European elderly. Eur J Clin Nutr. Nature Publishing Group; 2013;67(11):1215-9.

26. Saka B, Kaya O, Ozturk GB, Erten N, Karan MA. Malnutrition in the elderly and its relationship with other geriatric syndromes. Clin Nutr [Internet]. Elsevier Ltd; 2010;29(6):745-8. Available from: http://dx.doi.org/10.1016/j. clnu.2010.04.006

27. Gustafsson S. Health-promoting intervention for community-dwelling older adults Focusing on the concept of frailty and intervention outcome. 2012.

28. SCB. Befolkningens sammansättning 2014 Sverige [Internet]. 2014 [cited 2015 Sep 30]. Available from: http://scb.se/sv_/Hitta-statistik/Statistik-efteramne/Befolkning/Befolkningens-sammansattning/Befolkningsstatistik/\#c_ li_120253

29. Gustafsson S, Wilhelmson K, Eklund K, Gosman-Hedström G, Zidén L, Kronlöf $\mathrm{G}$, et al. Health-promoting interventions for persons aged 80 and older are successful in the short term--results from the randomized and three-armed Elderly Persons in the Risk Zone study. J Am Geriatr Soc. 2012 
Mar;60(3):447-54

30. Folstein MF, Folstein SE, McHugh PR. “Mini-mental state." J Psychiatr Res. 1975 Nov;12(3):189-98.

31. Augustsson O, Eriksson BG, Rosenhall U, Rothenberg E, Wärne B, Steen B. The Johanneberg study--a sociomedical survey in an urban elderly population. I. General presentation of the study including an analysis of nonresponse and identification of risk groups. Scand J Soc Med. 1994;22(4):28392.

32. Bertéus Forslund H, Lindroos AK, Sjöström L, Lissner L. Meal patterns and obesity in Swedish women-a simple instrument describing usual meal types, frequency and temporal distribution. Eur J Clin Nutr. 2002 Aug;56(8):740-7.

33. OxfordDictionaries.com. Oxford Advanced Learner's Dictionary [Internet]. 2015 [cited 2015 Dec 14]. Available from: http://www.oxforddictionaries. com/definition/english

34. Beck M, Ovesen L. At which body mass index and degree of weight loss should hospitalized elderly patients be considered at nutritional risk? Clin Nutr. 1998;17(5):195-8.

35. Dahlin-Ivanoff S, Gosman-Hedström G, Edberg A-K, Wilhelmson K, Eklund K, Duner A, et al. Elderly persons in the risk zone. Design of a multidimensional, health-promoting, randomised three-armed controlled trial for "prefrail" people of $80+$ years living at home. BMC Geriatr. 2010;10(27).

36. Socialstyrelsen, Folkhälsoinstitutet. Folkhälsan i Sverige. 2013.

37. Lindblad A, Rothenberg E, Dahlin-Ivanoff S, Bosaeus I. Body composition and hand grip strength in healthy community-dwelling older adults in sweden. J Aging Res Clin Pract. 2015;4(1):54-8.

38. Larsson K, Kåreholt I, Thorslund M. Care utilisation in the last years of life in Sweden: the effects of gender and marital status differ by type of care. Eur J Ageing. 2014 Sep 10;11(4):349-59.

39. Samhällsanalys och fakta Göteborgs stadsledningskontor. Äldres boende 2014 - områdesfakta [Internet]. 2014. Available from: http:/ / www4.goteborg. se/prod/G-info/statistik.nsf

40. Rychetnik L. Criteria for evaluating evidence on public health interventions. J Epidemiol Community Heal. 2002 Feb 1;56(2):119-27.

41. Power SE, O'Connor EM, Jeffery IB, O'Toole PW, Fitzgerald GF. Gender differences in food intake among Irish community-dwelling elderly subjects: The ELDERMET project. Proc Nutr Soc. 2012;71(July):2012.

42. Maharana B, Ladusingh L. Gender Disparity in Health and Food Expenditure in India among Elderly. Int J Popul Res. 2014;2014:1-8.

43. Sidenvall B, Nydahl M, Fjellström C. Managing food shopping and cooking: the experiences of older Swedish women. Ageing Soc. 2001;21(July 2001):15168.

44. Tinker A. Older people in modern society. Longman; 1997.
45. Dykstra PA. Changes in Older Adult Loneliness: Results From a Seven-Year Longitudinal Study. Res Aging. 2005 Nov 1;27(6):725-47.

46. McDonald J, Quandt S, Arcury T, Bell R. On their own: Nutritional selfmanagement strategies of rural widowers. Gerontologist. 2000;40(4):480-91.

47. Nyberg A. Arbetsmarknadsstatistiken - Ideologi eller verklighet? Arbetsmarknad \& Arbetsliv. 2005;11(1).

48. Gammal i folkhemmet | Nordiska museet [Internet]. [cited 2015 Jun 21]. Available from: http://www.nordiskamuseet.se/artiklar/gammal-ifolkhemmet

49. Fjellström C. Drömmen om det goda livet: Livskvalitet och matvanor i ett uppväxande industrisamhälle: Stocka sågverk 1870-1980 [The dream of the good life] [Internet]. [Stockholm]: Almqvist \& Wiksell International; 1990 [cited 2015 Apr 16]. Available from: http://lunda.ub.gu.se:8080/lib/ item theme $=$ gunda\&locale $=$ sv\&id $=$ chamo: 485385

50. L'Orange Fürst E. Cooking and femininity. Womens Stud Int Forum. 1997;20(3):441-9.

51. Savoca MR, Arcury TA, Leng X, Chen H, Bell RA, Anderson AM, et al Association between dietary quality of rural older adults and self-reported food avoidance and food modification due to oral health problems. J Am Geriatr Soc. 2010;58(7):1225-32.

52. Quandt SA, Chen H, Bell RA, Savoca MR, Anderson AM, Leng X, et al. Food avoidance and food modification practices of older rural adults: association with oral health status and implications for service provision. Gerontologist. 2010 Feb;50(1):100-11.

53. Österberg T, Johanson C, Sundh V, Steen B. Secular trends of dental status in five 70-year-old cohorts between 1971 and 2001. Community Dent Oral Epidemiol. 2006;34(6):446-54.

54. Hugoson A, Koch G. Thirty year trends in the prevalence and distribution of dental caries in Swedish adults (1973-2003). Swed Dent J. 2008;32(2):57-68.

55. Petersen PE, Yamamoto T. Improving the oral health of older people: the approach of the WHO Global Oral Health Programme. Community Dent Oral Epidemiol. 2005;33(2):81-92.

56. Basara BB, Mollahaliloglu S, Pulgat E, Kavuncubasi S. Gender and Residency Effects on Elderly Health in Turkey. Ageing Int. 2012 Aug 26;39(1):55-67.

57. Jeon GS, Jang SN, Rhee SJ, Kawachi I, Cho SI. Gender Differences in Correlates of Mental Health Among Elderly Koreans. Journals Gerontol Ser B Psychol Sci Soc Sci. 2007 Sep 1;62(5):S323-9.

58. Laudisio A, Marzetti E, Antonica L, Pagano F, Vetrano DL, Bernabei R, et al. Metabolic syndrome and quality of life in the elderly: age and gender differences. Eur J Nutr. 2013 Feb;52(1):307-16.

59. O'Connor EM, Fitzgerald GF, O'Toole PW. Gender differences in folate status are associated with cognition in healthy Irish elderly adults. Proc Nutr Soc. 2011 Aug 15;70(OCE3):E64. 